International Journal of Environmental Research and

Public Health

ISSN 1660-4601

www.mdpi.com/journal/ijerph

Article

\title{
Determination of Total Tritium in Urine from Residents Living in the Vicinity of Nuclear Power Plants in Qinshan, China
}

\author{
Bao-Ming Shen, Yan-Qin Ji *, Qing Tian, Xiang-Zhang Shao, Liang-Liang Yin and Xu Su \\ China CDC Key Laboratory of Radiological Protection and Nuclear Emergency, National Institute for \\ Radiological Protection, Chinese Center for Disease Control and Prevention, Beijing 100088, China; \\ E-Mails: shenbm9@ sina.com (B.-M.S.); bankvole@sohu.com (Q.T.); shaoxzh@nirp.cn (X.-Z.S.); \\ yinliangliang2010@163.com (L.-L.Y.); suxu@nirp.cn (X.S.)
}

* Author to whom correspondence should be addressed; E-Mail: jiyanqin @ nirp.cn; Tel./Fax: +86-10-6238-9639.

Academic Editor: Dietmar Knopp

Received: 23 October 2014 / Accepted: 12 January 2015 / Published: 16 January 2015

\begin{abstract}
To estimate the tritium doses of the residents living in the vicinity of a nuclear power plant, urine samples of 34 adults were collected from residents living near the Qinshan nuclear power plant. The tritium-in-urine (HTO plus OBT) was measured by liquid scintillation counting. The doses of tritium-in-urine from participants living at 2,10 and $22 \mathrm{~km}$ were in a range of $1.26-6.73 \mathrm{~Bq} / \mathrm{L}, 1.31-3.09 \mathrm{~Bq} / \mathrm{L}$ and $2.21-3.81 \mathrm{~Bq} / \mathrm{L}$, respectively, while the average activity concentrations of participants from the three groups were $3.53 \pm 1.62$, $2.09 \pm 0.62$ and $2.97 \pm 0.78 \mathrm{~Bq} / \mathrm{L}$, respectively. The personal committed effective doses for males were $2.5 \pm 1.7 \mathrm{nSv}$ and for females they were $2.9 \pm 1.3 \mathrm{nSv}$. These results indicate that tritium concentrations in urine samples from residents living at $2 \mathrm{~km}$ from a nuclear power plant are significantly higher than those at $10 \mathrm{~km}$. It may be the downwind direction that caused a higher dose in participants living at $22 \mathrm{~km}$. All the measured doses of tritiumin-urine are in a background level range.
\end{abstract}

Keywords: urine; tritium; concentration of tritium; committed effective dose 


\section{Introduction}

Release of tritium into the environment from heavy water reactor operation is increasing the concentrations of tritium in the atmospheric water vapor and tritium occurs in the form of tritiated water vapor (HTO) and TH [1,2] that can easily been inhaled and absorbed by breathing and skin exposure. In addition, the distribution of tritium in precipitation and river water are important sources for human exposure. In the human body, the HTO and TH can quickly form free water tritium (FWT) and organically bound tritium (OBT) which are distributed in the tissues and organs in the uniform manner [3]. Previous studies demonstrated that tritium causes ionizing radiation damage primarily on the radiosensitive leukocyte cells [4]. Some studies [5,6] have shown that the OBT contributes to 5\%-10\% internal radiation dose in occupationally exposed workers, while residents around NPPs is $26 \%-50 \%$, and the origin of OBT in body is dietary intake. Thus, monitoring the concentration of HTO and OBT in urine is important for the dose assessment of exposure to tritium. Here, the concentrations of tritiumin-urine (HTO plus OBT) from 34 participants living in the vicinity of a nuclear power plant were measured and the annual effective doses of exposure to tritium were evaluated as well.

\section{Experimental Section}

\subsection{Sample Collection and Preparation}

Thirty four (34) participants who were living within $30 \mathrm{~km}$ of the Qinshan nuclear power plant were selected. The ages of the 34 residents ranged from 18 to 49 years old and the participants include 23 males and 11 females. The urine samples were collected between $10 \mathrm{pm}$ to 6 am with a $120 \mathrm{~mL}$ sample cup. The collected samples were labeled and stored in fridge and treated the next day.

Before detection, 10 gram of potassium persulfate (99\%, analytical grade, Acros Organics, NJ, USA) was added in a distillation apparatus to $50 \mathrm{~mL}$ of the collected urine samples. This mixture was oxidized for $30 \mathrm{~min}$ and a total of $20 \mathrm{~mL}$ of distillate was collected as described before [7]. Four $\mathrm{mL}$ of distillate and $14 \mathrm{~mL}$ of scintillation cocktail (Ultima Gold LLT, Perkin Elmer Inc., Waltham, MA, USA) were placed in a glass vial, and the same conditions were used in duplicate. To one vial $0.1 \mathrm{~mL} 1.5 \mathrm{~Bq} / \mathrm{mL}$ tritium standard solution (China Institute of Atomic Energy, Beijing, China, specific activity $150 \mathrm{~Bq} / \mathrm{mL}$, uncertainty is 2.4\%), was subsequently added, the mixture was shaken and stored in the dark for $72 \mathrm{~h}$. Then the mixtures were determined by a TRI-CARB 3170 TR/SL (Perkin Elmer) liquid scintillation counter in lower level mode with the energy range $0 \sim 18.6 \mathrm{keV}$.

\subsection{Sample Analysis}

The concentration of tritium-in-urine (HTO plus OBT) was obtained with the following equation [7]:

$$
A=\left(N_{s}-N_{b}\right) / V \varepsilon
$$

where $A$ : the concentration of tritium-in-urine (HTO plus OBT), Bq/L; $V$ : the volume of the urine sample using the measurement, $\mathrm{L} ; \varepsilon$ : the counting efficiency of tritium, $\varepsilon=\left(N_{a}-N_{s}\right) / D, N_{a}$, tritium spiked sample count rate, counting $\cdot \mathrm{s}^{-1} ; \mathrm{D}$, tritium activity spiked, $\mathrm{Bq} ; N s$ : count rate of the sample, counting $\cdot \mathrm{s}^{-1}$; $N_{b}$ : the background count rate of the sample, counting $\cdot \mathrm{s}^{-1}$. The limited detection concentration $(L D C)$ and minimum detectable concentration $(M D C)$ of tritium in urine [8] were defined as: 
When the confidence level is $95 \%, \alpha=\beta=0.05, K=1.65 ; t b=t_{s}$.

$$
L D C=2.33 \sqrt{n_{b} / t_{b}} / V \varepsilon
$$

and $M D C=2 L D C$. Where the parameter $n_{b}=0.035 \mathrm{~s}^{-1}, t_{b}=60,000 \mathrm{~s}, \varepsilon=35.2 \%, V=4 \times 10^{-3} \mathrm{~L}$, the $L D C=1.26 \mathrm{~Bq} / \mathrm{L}$ and $M D C=2.52 \mathrm{~Bq} / \mathrm{L}$, respectively.

The coefficient of variation $(C V)$ for net counting and tritium counting efficiency are the main source of error in measuring the concentration of tritium-in-urine. The $C V$ of tritium concentration in urine is in the range of $13 \%$ to $29 \%$ as the tritium concentration in urine is greater than the $M D C$.

\subsection{Committed Effective Dose}

On the basis of adult intake of tritiated water, committed effective dose is estimated using the following parameters: total body mass is $73 \mathrm{~kg}$ for males and $60 \mathrm{~kg}$ for females. Water content of the body mass is $73 \%[9,10]$. Dose coefficient is $1.8 \times 10^{-11} \mathrm{~Sv} / \mathrm{Bq}$.

\section{Results and Discussion}

\subsection{Concentration of Tritium in-Urine}

The concentrations of tritium-in-urine from the 34 participants living in the vicinity of the Qinshan nuclear power plant were measured and the results were shown in Table 1. The concentration of tritiumin-urine was ranged from $L D C$ to $6.73 \mathrm{~Bq} / \mathrm{L}$, its $C V$ was $13-29 \%$ for greater than the detection limit $(M D C=2.52 \mathrm{~Bq} / \mathrm{L})$.

Table 1. The concentration of tritium-in-urine.

\begin{tabular}{cccccccc}
\hline ID No. & Gender & $\begin{array}{c}(\text { HTO plus OBT }) \\
(\mathbf{B q} / \mathbf{L})\end{array}$ & $\boldsymbol{C} \mathbf{V}(\boldsymbol{\%})$ & ID No. & Gender & $\begin{array}{c}(\mathbf{H T O} \text { plus OBT }) \\
(\mathbf{B q} / \mathbf{L})\end{array}$ & $\boldsymbol{C} \mathbf{V}(\boldsymbol{\%})$ \\
\hline 01 & Male & 6.16 & 14 & 18 & Male & 1.31 & 60 \\
02 & Male & 3.75 & 23 & 19 & Male & ND \# & \\
03 & Female & 3.91 & 20 & 20 & Female & 2.17 & 36 \\
04 & Female & 3.23 & 25 & 21 & Male & ND & \\
05 & Female & 6.73 & 13 & 22 & Female & 1.61 & 49 \\
06 & Male & 3.82 & 20 & 23 & Male & 1.65 & 45 \\
07 & Male & ND & & 24 & Female & ND & \\
08 & Male & 1.26 & 62 & 25 & Male & 2.27 & 36 \\
09 & Male & 2.69 & 29 & 26 & Female & 2.81 & 30 \\
10 & Female & 4.66 & 20 & 27 & Male & 1.79 & 45 \\
11 & Male & 2.89 & 28 & 28 & Male & ND & \\
12 & Male & 1.44 & 54 & 29 & Male & 3.81 & 23 \\
13 & Male & 1.76 & 42 & 30 & Female & ND & \\
14 & Male & 2.41 & 34 & 31 & Female & 2.41 & 35 \\
15 & Male & 3.12 & 26 & 32 & Male & 3.46 & 25 \\
16 & Male & 5.18 & 16 & 33 & Female & 2.21 & 35 \\
17 & Male & 3.09 & 25 & 34 & Male & ND & \\
\hline
\end{tabular}

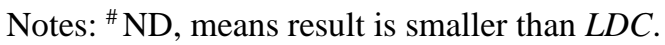


The sampling points of residents living at 2, 10 and $22 \mathrm{~km}$ are shown in Table 2 . The concentrations of tritium-in-urine (samples 1 to 16) from participants living at $2 \mathrm{~km}$ were in a range of $1.26-6.73 \mathrm{~Bq} / \mathrm{L}$, with an average value of $3.53 \pm 1.62 \mathrm{~Bq} / \mathrm{L}$. The measurement of urine samples from $10 \mathrm{~km}$ (numbers 17 to 28 ) were $1.31-3.09 \mathrm{~Bq} / \mathrm{L}$, with an average value of $2.09 \pm 0.62 \mathrm{~Bq} / \mathrm{L}$, while the concentration of tritium-in-urine from residents living at $22 \mathrm{~km}$ (numbers 29 to 34 ) ranged from $2.21-3.81 \mathrm{~Bq} / \mathrm{L}$ and the average value was $2.97 \pm 0.78 \mathrm{~Bq} / \mathrm{L}$. The results of urine tritium concentration in local residents were significantly different $(p<0.05$, SPSS13.0, $\mathrm{t}=3.065)$ between the $2 \mathrm{~km}$ and $10 \mathrm{~km}$ sampling points. As for the $22 \mathrm{~km}$ distance sampling point, the values showed no significant difference compared with the 2 $\mathrm{km}$ sampling point. The main reason was the dominant wind direction on the Zhejiang coast, which was a wind from March to August (Figure 1). The samples were collected in July, so the southeast wind affected tritium concentration of water and atmosphere in the region. Additionally, the Qin Mountain located at the southwest direction of Qinshan NPPs, which might be a natural barrier preventing tritium dispersion in southwest direction [2].

Table 2. The average concentration of tritium that populations living at different distances and orientation of urine samples.

\begin{tabular}{ccccc}
\hline ID No & $\mathbf{N}^{*}$ & Location & Range, HT and BT $(\mathbf{B q} / \mathbf{L})$ & Mean, HT and BT $(\mathbf{B q} / \mathbf{L})$ \\
\hline $01-16$ & 15 & Southwest, 2 km & $1.26-6.73$ & $3.53 \pm 1.62$ \\
$17-28$ & 8 & Southwest, 10 km & $1.31-3.09$ & $2.09 \pm 0.62$ \\
$29-34$ & 4 & Northwest, 22 km & $2.21-3.81$ & $2.97 \pm 0.78$ \\
\hline
\end{tabular}

Notes: "The number of samples whose value were higher than LDC.

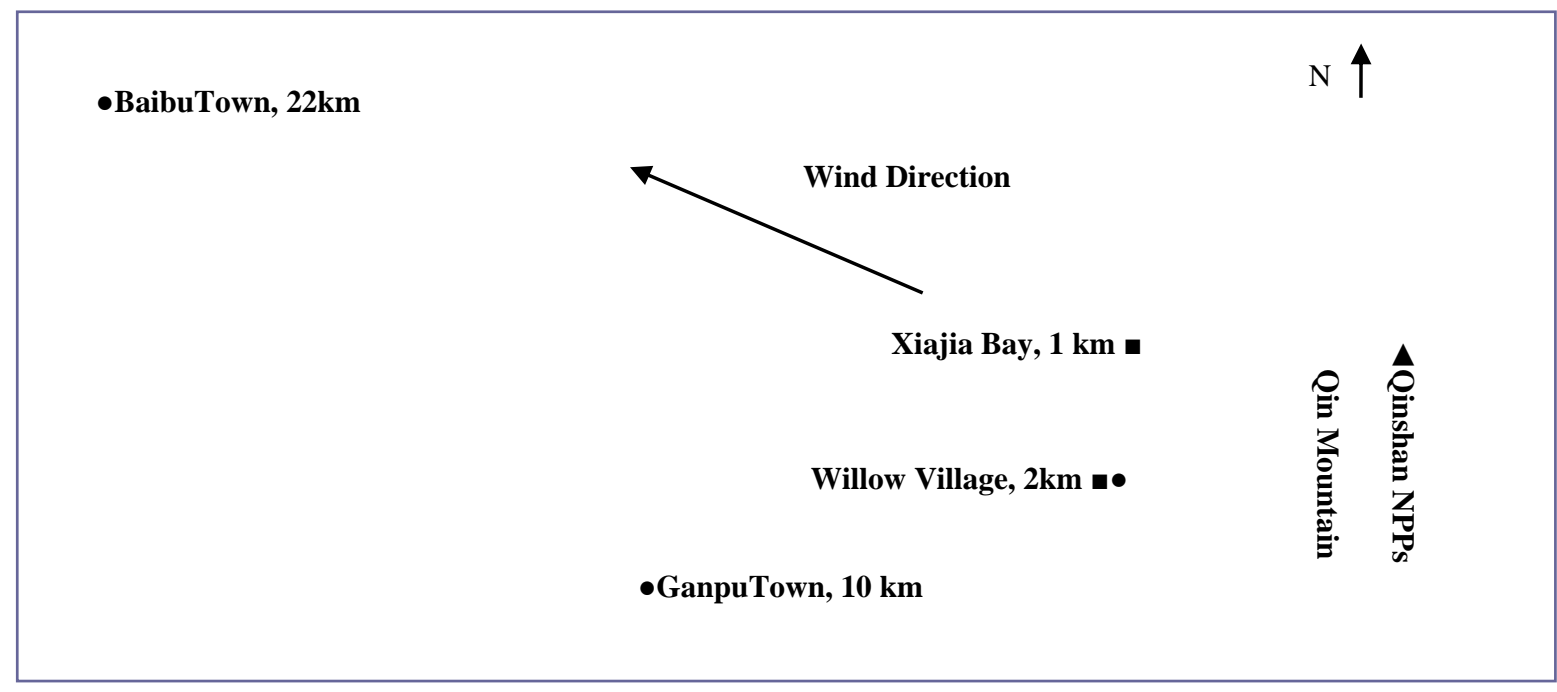

Figure 1. Sketch of wind direction, sampling points and monitoring sites. a Monitoring sites in reference 2; • Sampling Point in this work.

\subsection{Dose of Tritium Contribution}

The committed effective dose of participants was calculated on the basis of the measured results and the parameters for tritium recommended by the ICRP [9,10]. It was $2.5 \pm 1.7 \mathrm{nSv}$ for males and $2.9 \pm 1.3 \mathrm{nSv}$ for females. 
Table 3. Tritium concentration in urine and committed effective doses for the exposed workers and the general public for tritium according to reported in the literature.

\begin{tabular}{|c|c|c|c|c|c|c|}
\hline \multirow[t]{2}{*}{ Country/Region } & \multirow[t]{2}{*}{$\mathbf{n}$} & \multirow{2}{*}{$\begin{array}{l}\text { Mean } \\
(B q / L)\end{array}$} & \multirow{2}{*}{$\begin{array}{c}\operatorname{Rang}^{\# \#} \\
(\mathbf{B q} / \mathrm{L})\end{array}$} & \multicolumn{2}{|c|}{$\begin{array}{c}\text { Committed Effective Dose } \\
\qquad E(\mathbf{n S v})\end{array}$} & \multirow[t]{2}{*}{ References } \\
\hline & & & & Males & Females & \\
\hline China/Sichuan & & & $4.4-12.6$ & & & [11] \\
\hline $\begin{array}{l}\text { Canada/AECL }{ }^{\#} \text { southeast } 0.6-200 \\
\text { km }\end{array}$ & 5 & & $6.5-53$ & & & {$[5]$} \\
\hline $\begin{array}{l}\text { Korea/who do not work at a nuclear } \\
\text { facility }\end{array}$ & 50 & $2.8 \pm 1.4$ & $1.8-5.6$ & $1.9 \pm 0.7$ & $2.4 \pm 1.1$ & [12] \\
\hline Finland, Helsinki & 227 & 2.55 & $1.5-18.3$ & 2.4 & & [13] \\
\hline China/Vicinity of NPPs & 27 & $\begin{array}{c}3.02 \pm \\
1.42\end{array}$ & $1.26-6.73$ & $2.5 \pm 1.7$ & $2.9 \pm 1.3$ & This work \\
\hline
\end{tabular}

Notes: \#AECL-Chalk River Laboratories; \#\# reported in the literature HTO, this work is HTO plus BTO.

\section{Conclusions}

With the increase of nuclear power plants in recent years, the release of tritium in the form of TH and tritiated water vapor from reactor operations into the environment is increasingly influencing the surrounding environment $[2,5]$. The results of this study showed that concentrations of total tritium-inurines from participants living $2 \mathrm{~km}$ in the southwest direction from a nuclear power plant were significantly higher $(p<0.05$, SPSS13.0, $\mathrm{t}=3.065)$ than the average of urine samples from residents living at $10 \mathrm{~km}$ from the plant. The average concentration of tritium-in-urine from people living at $22 \mathrm{~km}$ from the nuclear power plant was $2.97 \pm 0.78 \mathrm{~Bq} / \mathrm{L}$. This may due to the northwest direction which is the dominant downwind direction of the nuclear power plant, in which the orientation of atmospheric HTO and TH were significantly higher than in the southwest direction. The annual average tritium concentration of atmospheric of Xiajia Bay and Willow village (Figure 1) were 348 and $101 \mathrm{mBq} / \mathrm{m}^{3}$ [2].

Compared with the concentrations of tritium-in-urines from residents living in the vicinity of a decommissioning of nuclear facilities is in a range of 4.38-12.57 Bq/L [11], and from 50 Koreans who do not work at a nuclear facility it ranged $1.8-5.6 \mathrm{~Bq} / \mathrm{L}[12]$, and the mean activity concentration of tritium in the urine of Finnish people is $2.55 \mathrm{~Bq} / \mathrm{L}$ and the maximum $18.3 \mathrm{~Bq} / \mathrm{L}$ [13]. Our results (1.26 6.73 Bq/L) show the similar ranges of tritium-in-urine (Table 3). The analytical method used measured total tritium and it does not therefore detect OBT. With tritiated water dose coefficients $(1.8 \times$ $10^{-11} \mathrm{~Sv} / \mathrm{Bq}$ ) [9] applied directly to the body effective dose calculated in this way may be underestimated. For males and females they were $2.5 \pm 1.7 \mathrm{nSv}$ and $2.9 \pm 1.3 \mathrm{nSv}$, respectively. The reason is that the OBT dose coefficient $\left(4.2 \times 10^{-11} \mathrm{~Sv} / \mathrm{Bq}\right)$ [9] is higher than for tritiated water. As such, the continuous chronic intake estimates of the dose due to the public are reasonable. In short, since these results were much lower than the dose limit for the public, background information is provided for reference only.

\section{Acknowledgments}

The authors acknowledge financial support by the Chinese Ministry of Health (Grant No. 201002009), and by the Chinese Ministry of Science and Technology (Grant No. 2013BAK03B00). The 
authors thank the Zhejiang Center for Disease Control and Prevention, Xuan Zhiqiang, Li Xinxing and Yu Shunfei for support of urine sampling.

\section{Author Contributions}

Bao-Ming Shen performed the experimental work. Yan-Qin Ji conceived the work and designed the experiments. Xu Su and Yan-Qin Ji supervised the project. Bao-Ming Shen and Yan-Qin Ji analyzed the data and wrote the manuscript. Qing Tian, Xiang-Zhang Shao and Liang-Liang Yin contributed sampling and pretreatment.

\section{Conflicts of Interest}

All authors declare they have no conflict of interest to disclose in the context of this study.

\section{References}

1. Deng, F.; Chen, Z.D.; Lin, Q.; Ouyang, J.J.; Ji, C.Y.; Xi, S.F. Source of ${ }^{3} \mathrm{H}$ in monitored well water at Dayawan Nuclear Power Station. Radiat. Prot. Bull. 2006, 26, 10-14. (In Chinese)

2. Cao, Z.G.; Ye, J.D.; Wang, H.F.; Chen, Q.Y.; Huang, R.J. Monitoring of ${ }^{3} \mathrm{H}$ and ${ }^{14} \mathrm{C}$ level in air external environment around QNPPs. Radiat. Prot. Bull. 2006, 26, 17-20. (In Chinese)

3. Ma, Y.R.; Jin, Y.R. Zhang, X.Z. Evalution of intake conversion factor for tritiated water. Radiat. Prot. Bull. 1990, 1, 74-77. (In Chinese)

4. Milacić, S. Changes in leukocytes caused by tririum contamination. Health Phys. 2004, 86, 457459.

5. Kotzer, T.; Trivedi, A. Dosimetric implications of atmospheric dispersal of tritium near a heavywater research reactior facility. Radiat. Prot. Bull. 2001, 93, 61-66.

6. International Commission on Radiological Protection. Limits for Intakes of Radionuclides by Workers; ICRP Publication 30; Pergamon: Oxford, UK, 1980.

7. Chinese Standards. Analytical Determination of Tritium in Urine; EJ/T 1047-1997; China National Nuclear Corporation: Beijing, China, 1997.

8. Zhang, J.Y.; Zhu, H.D. Food Radioactivity and due to the Radiation Dose; China Environmental Science Press: Beijing, China, 1989, (In Chinese)

9. International Commission on Radiological Protection. Individual Monitoring for Internal Exposure of Workers; ICRP Publication 78; Pergamon: Oxford, UK, 1997.

10. International Commission on Radiological Protection. Basic Anatomical and Physiological Data for Use in Radiological Protection: Reference Values; ICRP Publication 89, Ann. ICRP 32(3/4); Pergamon: Oxford, UK, 2002.

11. Wang, L.X.; Ruan, G.L.; Shi, Z.K. Measurement of Tritium in urine and study on half-time of Tritium excretion of men. Yunnan Environ. Sci. 2000, 19, 215-218. (In Chinese)

12. Yoon, S.; Ha, W.H.; Lee, S.S. Tritium analysis of urine samples from the general Korean public, Appl. Radiat. Isot. 2013, 81, 276-278. 
13. Puhakainen, M.; Heikkinen, T. Tritium in urine in Finnish people. Radiat. Prot. Dosim. 2008, 128, 254-257.

(C) 2015 by the authors; licensee MDPI, Basel, Switzerland. This article is an open access article distributed under the terms and conditions of the Creative Commons Attribution license (http://creativecommons.org/licenses/by/4.0/). 